\title{
Nurses' recommendations to the psychoaffective dimensions of patients hospitalized in nephrology
}

\author{
Recomendações de enfermeiros às dimensões psicoafetivas de pacientes hospitalizados em nefrologia
}

Recomendaciones de enfermeras a las dimensiones psicoaffectivas de pacientes hospitalizados en nefrología

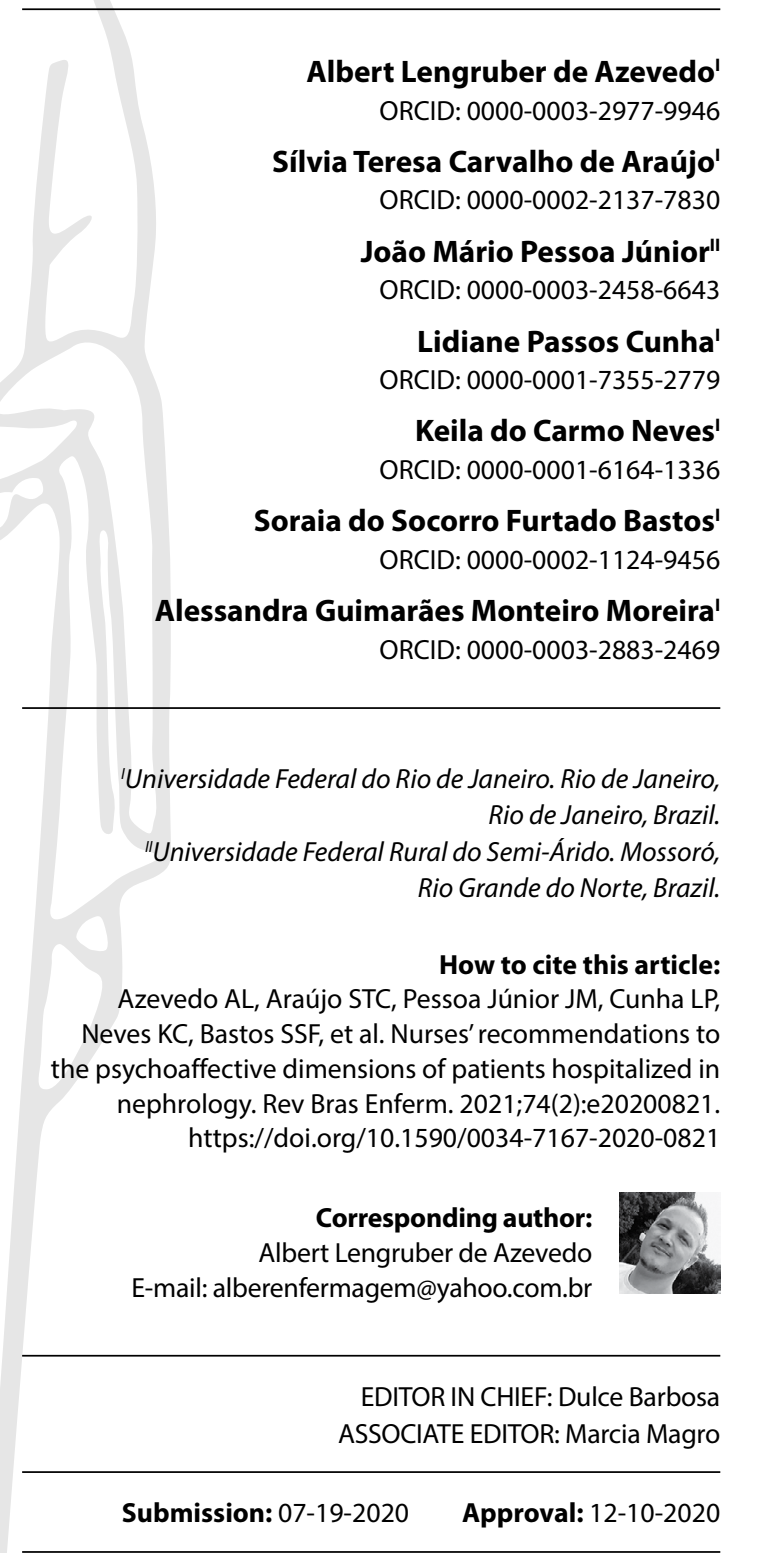

\begin{abstract}
Objectives: to analyze nurses' recommendations on the psycho-affective dimensions of patients hospitalized in nephrology. Methods: a qualitative, exploratory and descriptive study, carried out by applying a sociodemographic and training questionnaire, reading a clinical case and conducting a semi-structured interview. Fourteen nurses from a reference hospital in nephrology in the Southeast participated. In the technical input of data treatment, thematic content analysis was used. Results: the recommendations included the exercise of empathy; monitoring of emotions from the implementation of the nursing consultation; continuous sharing of tensions, anxieties and desires; knowledge of one's emotion; increased availability to listen; effectiveness of the approach in teams and social groups. Conclusions: recognizing patients' psycho-affective dimensions, in the context of nurses' performance, favors the expansion of therapeutic listening spaces, welcoming and interpersonal coexistence in nephrology, essential in the production of comprehensive health care. Descriptors: Nursing Care; Affect; Patients; Hospitalization; Nephrology.
\end{abstract}

\section{RESUMO}

Objetivos: analisar as recomendações de enfermeiros sobre as dimensões psicoafetivas de pacientes hospitalizados em nefrologia. Métodos: estudo qualitativo, exploratório e descritivo, realizado mediante aplicação de questionário sociodemográfico e de formação, leitura de caso clínico e realização de entrevista semiestruturada. Participaram 14 enfermeiros de hospital referência em nefrologia da Região Sudeste. No aporte técnico de tratamento dos dados, utilizou-se a análise de conteúdo temática. Resultados: as recomendações contemplaram o exercício da empatia; monitoramento das emoções a partir da implementação da consulta de enfermagem; compartilhamento contínuo das tensões, anseios e desejos; conhecimento da própria emoção; ampliação da disponibilidade para ouvir; efetivação da abordagem em equipe e grupos de convivência. Conclusões: o reconhecimento das dimensões psicoafetivas de pacientes, no contexto da atuação do enfermeiro, favorece a ampliação dos espaços de escuta terapêutica, acolhimento e convivência interpessoal na nefrologia, essenciais na produção do cuidado em saúde integral.

Descritores: Cuidados de Enfermagem; Afeto; Pacientes; Hospitalização; Nefrologia.

\section{RESUMEN}

Objetivos: analizar las recomendaciones de enfermeras sobre las dimensiones psicoafectivas de los pacientes hospitalizados en nefrología. Métodos: estudio cualitativo, exploratorio y descriptivo, realizado mediante la aplicación de un cuestionario sociodemográfico y formativo, la lectura de un caso clínico y la realización de una entrevista semiestructurada. Participaron 14 enfermeras de un hospital de referencia en nefrología de la Región Sureste. En el insumo técnico de tratamiento de datos se utilizó el análisis de contenido temático. Resultados: las recomendaciones incluyeron el ejercicio de la empatía; seguimiento de las emociones desde la implementación de la consulta de enfermería; compartir continuamente tensiones, ansiedades y deseos; conocimiento de la propia emoción; mayor disponibilidad para escuchar; efectividad del enfoque en equipos y grupos sociales. Conclusiones: el reconocimiento de las dimensiones psicoafectivas de los pacientes, en el contexto de la actuación del enfermero, favorece la ampliación de espacios de escucha terapéutica, recepción y convivencia interpersonal en nefrología, imprescindibles en la producción de una atención integral de salud.

Descriptores: Atención de Enfermería; Afecto; Pacientes; Hospitalización; Nefrología. 


\section{INTRODUCTION}

Nursing care in nephrology focuses on a complex universe of meanings implicit in their daily actions and actions, whether in the therapeutic bond established with patients, in the care provided, in the interaction with the team and family, or even in the development and use of educational health strategies ${ }^{(1)}$. In this scenario, among the different people involved in this process, nursing, patient and family, emotions, sensations and affections intermingled with each other, sometimes in a triad in which external elements linked to specific behaviors and demands permeate. caution ${ }^{(2)}$.

Chronic kidney disease (CKD) is known to significantly alter the life context of patients and their families, considering the effects and behavioral responses generated by diagnosis and treatment ${ }^{(3-4)}$. During hospitalization, challenges such as forming a bond with the team and patient, the mechanisms of acceptance experienced, the relationship between family, cycle of friends and the community, among others, together, signal the breadth and scope of nursing practice in nephrology ${ }^{(5)}$.

Thinking about the psycho-affective dimensions of hospitalized patients in this context requires nurses to use tools such as communication, interaction, dialogue, listening and availability, as it is an essential dialogue mechanism for nursing care capable of strengthening the adherence, adaptation and recovery process amid the limitations imposed by the disease ${ }^{(2,6)}$

It is understood that caring for nurses encompasses a complex arsenal of techniques and technologies integrated in thinking, doing and assisting the human being developed by professionals, with a view to improving patients' and family's quality of life $\mathrm{e}^{(1)}$. In this process, it is essential to develop tools and skills related to technical and humanistic capacity in dealing with emotional and intersubjective aspects in nephrology, favoring therapeutic listening in the context of nursing care ${ }^{(5-6)}$.

In hospital environments such as nephrology, nurses come to live with the duality of patients' perceptions and feelings, which may, in some cases, reveal problems of low self-esteem, anxiety, emotional instability, loss or decrease in daily activities, suffering and fear of death ${ }^{(1,4,7)}$. Such aspects may be associated with not understanding the health-disease process, environmental factors and insecurity for not knowing how to behave and adapt in the face of adverse situations ${ }^{(2)}$.

In this context, there are still obstacles in the practice of nurses focused on biological or technical aspects of patients, which significantly contributes to the increase in stress and fear commonly identified in CKD treatment ${ }^{(7)}$. In some cases, dealing with emotions and affections ends up being neglected by professionals, making it difficult to establish a bond, dialogue, in addition to adherence to treatment ${ }^{(5)}$.

The attention to the psycho-affective dimensions of patients hospitalized in nephrology by nurses favors the creation of a welcoming space, empathy and trust to understand others and themselves, as well as, at times, strengthens spiritual and emotional support during hospitalization ${ }^{(2,6)}$. That said, the following guiding question was outlined for this study: what recommendations are made by nurses to meet the psycho-affective dimensions of patients hospitalized in nephrology?
It is recognized that attention to psycho-affective dimensions in nephrology enhances the intersubjective production of comprehensive nursing care, expanding the therapeutic bases of interaction, respect, and ethics ${ }^{(2-3)}$.

\section{OBJECTIVES}

To analyze nurses' recommendations on the psycho-affective dimensions of patients hospitalized in nephrology.

\section{METHODS}

\section{Ethical aspects}

This study was attentive to national and international standards of ethics in research involving human beings, being approved by a Research Ethics Committee. Participants' anonymity was ensured and their testimonies were identified with the initial letter $\mathrm{N}$ for the word "Nurse", followed by an alphanumeric order (1, 2, 3, up to 14) according to the final code presented (N1, N2, N3, up to N14).

\section{Type of study}

This is a qualitative, exploratory and descriptive study.

\section{Methodological procedures}

Initially, there was a visit to the service and contact with the Head of Nursing, at which point it was clarified that the conduct of the research would keep the assistance to patients assured and uninterrupted. With that being said, the researcher was inserted and familiarized with the service by meeting nurses to clarify the study, clarify any doubts and schedule the collection. Contact with these professionals took place privately, and the interviews took place according to the established schedule, in a rotation system, usually between the hours of 3:00 pm to 5:00 pm and from 7:00 pm to 9:00 pm.

Fourteen nurses participated in the study, aged between 30 and 55 years, being nurses responsible for patient care on day and night shifts and with at least six months of experience in the nephrology sector. Nurses who did not participate in any data collection and being on sick leave were excluded. For data saturation, it was considered the repetition of the responses in the time spent by each nurse during the production stages resulting from the reading of the clinical case, the individual responses in the printed questionnaire to identify the diagnoses and the information and recommendations suggested in the semi-structured interview.

\section{Study setting}

It was an anteroom of a large university hospital, a reference in nephrology, located in the metropolitan region of the state of Rio de Janeiro, Brazil. The choice was made because this is a possible space to be occupied for research and because it is familiar to nurses, who commonly use it to hold meetings, conversations, debates, lectures, training, qualification and updates with other nursing professionals. 


\section{Data collection and organization}

Data production took place from November 2017 to April 2018. Initially, nurses were invited to participate in the research, followed by reading the Informed Consent Term (ICF). Upon acceptance, the instrument containing text typed and printed on A4 sheet on the clinical case was delivered, made from the scientific and diagnostic evidence identified in the clinical specialty. After reading the case, participants listed the main nursing diagnoses and the recommendations for each one.

In the second step, the questionnaire was applied, covering socio-demographic data and training of professionals; then, a semi-structured interview was conducted, recorded on a digital device (MP3 format), with the central guiding question: what are your recommendations for meeting the psycho-affective dimensions of patients hospitalized in nephrology? After transcribing the testimonies, reading and rereading the material produced made it possible to know the emotional and affective responses perceived by professionals about patients with CKD.

It is noteworthy that each nurse shared his impressions about the relevant elements from the instrument, describing recommendations according to the care of the psycho-affective dimensions of patients in hospitalization in nephrology through reflection and criticism about the care provided. To maintain the data organization process rigor, the criteria established in the COnsolidated criteria for REporting Qualitative research $(\mathrm{COREQ})^{(8)}$ was used.

\section{Data analysis}

Thematic content analysis was used as a technical contribution, since its use presupposes the following of different stages, namely: pre-analysis; material exploration or coding; treatment of results; inference; interpretation ${ }^{(9)}$. Transcripts of the testimonies recorded in full, text skimming and an exhaustive rereading of the material produced were carried out.

Thematic analysis of the corpus considered the most frequent records ${ }^{(9)}$. At the end, a large category was identified, entitled "Recommendations for the psycho-affective dimensions of patients hospitalized in nephrology" from their registration units.

\section{RESULTS}

The study participants were all nurses working in the nephrology service $(n=14)$, mostly women $(n=10)$, married $(n=10)$, aged between 30 and 45 years $(n=10)$ and between 45 and 55 years old $(n=4)$.

Considering the technical support adopted and the testimony analysis process, the main nurses'recommendations on patients' psycho-affective dimensions and their respective definitions were identified. Chart 1 was elaborated, systematizing the main thematic category, covering the seven registration units and the respective testimonies illustrating each one.

The recommendations included the exercise of empathy, the professionals' ability to look beyond the disease, respecting patients' individuality; monitoring of emotions, from the implementation of the nursing consultation and its main stages; the need for continuous sharing of tensions, anxieties and desires; have a look beyond the machine; pay attention to the recognition of one's emotion and to the psycho-affective aspects of taking care properly; increased availability to listen; strengthening the bond; effective team approach, especially integrating nursing; effecting the creation of coexistence groups in the service.

Chart 1 - Nurses' recommendations on the psycho-affective dimensions of patients hospitalized in nephrology

\begin{tabular}{|c|c|}
\hline Records Unit & Statements \\
\hline Empathy exercise & $\begin{array}{l}\text { [...] the first exercise is empathy. It is } \\
\text { looking at patients not from their } \\
\text { pathology, but from far beyond it. } \\
\text { (N3) } \\
\text { [...] I need to know if he is receptive, } \\
\text { as he can often feel attacked. If he is } \\
\text { receptive, I will hold his hand, look at } \\
\text { him, in his eyes, speak calmly about } \\
\text { what needs to be changed. (N8) } \\
\text { [...] sometimes we think that patients } \\
\text { with chronic kidney disease are } \\
\text { the same as everyone. No. It is } \\
\text { individualized! [...] when nurses } \\
\text { identify what he needs, know what } \\
\text { to do to improve his life. (N1) }\end{array}$ \\
\hline $\begin{array}{l}\text { Monitoring of emotions, from } \\
\text { nursing consultations }\end{array}$ & $\begin{array}{l}\text { The nursing consultation, the nursing } \\
\text { evaluation itself. But it is very difficult } \\
\text { to be able to talk to all patients on a } \\
\text { daily basis. You end up talking more } \\
\text { with those who are entering, who } \\
\text { are starting treatment, because they } \\
\text { come with more doubts, with greater } \\
\text { need for care. (N7) } \\
\text { [...] that an initial consultation } \\
\text { was made, a nursing consultation, } \\
\text { mainly with hemodialysis patients. } \\
\text { (N10) } \\
\text { Through an interview, an anamnesis } \\
\text { that could be done every month, } \\
\text { every week. [...] to view the problems } \\
\text { it will present; and nurses interfere as } \\
\text { needed. (N4) }\end{array}$ \\
\hline $\begin{array}{l}\text { Continuous sharing of } \\
\text { tensions, anxieties and desires }\end{array}$ & $\begin{array}{l}\text { We pay a lot of attention to } \\
\text { management, a lot of attention } \\
\text { to scale, a lot of attention to the } \\
\text { hemodialysis machine, because even } \\
\text { today, the machine is considered } \\
\text { the differential within hemodialysis. } \\
\text { The machine is the one that scares, } \\
\text { the machine is the one that gives } \\
\text { problems, the machine is the big star } \\
\text { of the situation, when in fact the big } \\
\text { star should be patients being treated. } \\
\text { (N5) } \\
\text { [...] I think this issue of individualizing } \\
\text { patients, seeing them as a whole, this } \\
\text { helps a lot. (N1) }\end{array}$ \\
\hline Recognition of one's emotion & $\begin{array}{l}\text { [...] that nurses are open, that they } \\
\text { allow themselves to be aware of the } \\
\text { psycho-affective dimensions, which } \\
\text { are not always included in their } \\
\text { actions. (N2) }\end{array}$ \\
\hline
\end{tabular}

To be continued 
Chart 1 (concluded)

\begin{tabular}{|c|c|}
\hline Records Unit & Statements \\
\hline Increased availability to listen & $\begin{array}{l}\text { [...] nurses will only be able to reach } \\
\text { these psycho-affective dimensions [...] if } \\
\text { he is willing to listen to [...] and still [...] to } \\
\text { establish dialogue; create a bond with } \\
\text { patients; to be willing to listen to. (N6) } \\
\text { Nurses guide, guide, guide, and do not } \\
\text { listen [...] many times, patients want to } \\
\text { talk, but nurses are more concerned } \\
\text { with passing on information. (N8) } \\
\text { [...] I would observe. And to attend, } \\
\text { Iwould always talk to this patient, } \\
\text { keep close, ask some simple questions, } \\
\text { such as: how was your day? How are } \\
\text { you? How was the week? How are you } \\
\text { feeling? trying to open a dialogue, and } \\
\text { from that opening, I will go deeper. } \\
\text { (N13) } \\
\text { [...] listening a lot, being able to listen, } \\
\text { observing, using communication, } \\
\text { mainly, to understand this patient as a } \\
\text { whole. (N14) } \\
\text { [...] it is very complicated for you to talk } \\
\text { to patients inside the dialysis room, } \\
\text { why? Because the friend listens to what } \\
\text { you say. (N7) }\end{array}$ \\
\hline Effective team approach & $\begin{array}{l}\text { Ifyou are a nurse leader on duty, } \\
\text { you will involve the team, you will } \\
\text { supervise, you will see if the team is } \\
\text { dealing with patients in a welcoming } \\
\text { way, in a pleasant way, if you are being } \\
\text { cordial, and if you are being able to } \\
\text { listen to patients. [...] sometimes, nurses } \\
\text { encourage the team, but the dynamics } \\
\text { of the dialysis center itself do not allow } \\
\text { this to happen. The direction of nursing } \\
\text { ends up being inferior, according to the } \\
\text { Ordinance, with RDC, which says that } \\
\text { it can be a nurse for every } 75 \text { patients, } \\
\text { but it is not possible. (N2) } \\
\text { First study. Always watching, reading } \\
\text { articles by other nurses [...] seeking } \\
\text { to bring me the experience of others, } \\
\text { reading articles on mental health, } \\
\text { reading books and listening to. (N14) } \\
\text { I think that having the resources to } \\
\text { welcome and encourage patients is as } \\
\text { important as knowing how to perform } \\
\text { a well-made puncture, how to handle } \\
\text { hemodialysis equipment safely. [...] } \\
\text { having a nurse equipped to deal with } \\
\text { psycho-affective dimensions is as } \\
\text { important as mastering the technique, } \\
\text { handling the machine, performing } \\
\text { the dressing on the catheter. In my } \\
\text { view, there are two aspects that } \\
\text { complement each other: the safe } \\
\text { performance of the technique and the } \\
\text { fulfillment of these psycho-affective } \\
\text { dimensions of patients. (N11) }\end{array}$ \\
\hline Effectiveness of social groups & $\begin{array}{l}\text { [...] that nurses negotiate with the } \\
\text { direction of the dialysis center, and that } \\
\text { he [...] try to establish social groups, } \\
\text { where people can talk in the presence } \\
\text { of psychologists or that nurses can be } \\
\text { facilitators of these meetings. (N2) }\end{array}$ \\
\hline
\end{tabular}

\section{DISCUSSION}

Nephrology nursing deals daily with several patients and with the respective treatment modalities. Of these, a look focused on the psycho-affective dimensions is required, that is, that goes beyond the physiological aspects of CKD, sometimes intermingled in a therapeutic relationship and with the recognition of self-esteem, emotions and affections ${ }^{(2-3)}$.

Study participants consider that the role of nurses in the nephrology scenario implies, above all, the exercise of empathy, which reflects in professionals' ethical behavior and the ability to put oneself in the other's place or vice versa ${ }^{(10)}$. The exercise of empathy requires attitudes that transform relationships between people, strengthening the bond between those who care and those who are being cared for, making them beneficial and positive.

In this scenario, situations such as patients' physiological and clinical changes may require nurses to adapt their approach in order to keep it therapeutic. Hostility and aggression behaviors can be caused by elevated urea and creatinine, indicating possible neuropsychiatric manifestations such as anxiety and depression, resulting, sometimes, from decreased immunity, insecurity, losses, anguish and fear of the unknown ${ }^{(7)}$.

Nurses emphasize that sensitive and empathic nursing care improves therapeutic adherence, especially during hospitalization, considering aspects related to the entry, stay and departure of patients in the hospital ${ }^{(1-3)}$. Generally, the routine of care involves the regular use of medications, monitoring vital signs, performing diagnostic tests, after dietary and exercise protocols, abstinence from substance abuse and regular monitoring by experts ${ }^{(11)}$.

It is understood that the way patients experience treatment is personal, that is, each one develops their own mechanisms, which can be of tolerance, frustrations, maintaining relationships, or even future projects. Some cope better with the disease, seeking information and motivation, others have greater difficulties and seek alternatives to adapt to the new lifestyle ${ }^{(12-13)}$.

The initiative is to instruct them every day about this process, so that they learn to deal with their own behaviors and also with their emotion $\mathbf{s}^{(12)}$. Maintaining an attentive and qualified listening, an effective dialogue and a broader view are actions that can favor self-care, improve adherence to treatment and also strengthen the bond between those who care and are cared for, making it, in addition to being instrumental-technical, therapeutic ${ }^{(3,13)}$.

In this experience, nurses realized that behaviors are producers of health care. All recognized that they need to perceive patients more during their stay in the hospital, look at it in full, knowing how to welcome and encourage them to self-care ${ }^{(11,14)}$. Those who help, who perceive the psycho-affective dimensions in others, naturally exercise empathy. It is empathy that gives time and voice to the various nuances of human care, making it safe, comprehensive, sensitive and welcoming ${ }^{(3,15)}$.

They also recognized that they need to adopt a more open posture when interacting with patients, develop self-perception, making the habit of sensitive listening and enlarged gaze ${ }^{(3,15)}$. As they are actions of a therapeutic nature, they are aimed at rethinking the approach, providing guidance and clarifying doubts, and technical care, how to handle the machine, puncture the arteriovenous fistula, make the dressing, even perform a nursing consultation ${ }^{(1,16)}$. 
There were countless managerial issues raised by nurses, which, if not considered fundamental, can significantly change the pattern of patients' daily self-care ${ }^{(4,6)}$. Among them is the nursing consultation, a health tool that requires a shared and aligned approach from the team. Putting it into practice in nephrology demands availability to listen, in addition to the understanding that this is a tool that cannot, in any way, be discredited or have its content emptied ${ }^{(16)}$. It is through it that nurses establish healthy habits, monitor emotions, teaching self-care ${ }^{(2)}$.

Managing requires, therefore, the mastery of this plurality, the continuous sharing of tensions, anxieties and desires, emotional selfrecognition - since the fundamental principles of care, in collective spaces, tend to achieve success only from the effective articulation between the spheres administrative, assistance, educational and research. Both must happen in an active, critical and purposeful way ${ }^{(17)}$.

Although the machine is considered by participants the protagonist and fundamental element to the health of patients who are there, it is also the major generator of changes in emotional patterns. For those who depend on a machine to obtain a better quality of life, it is expected to develop strategies such as social groups that allow them to improve their relationship with the process itself, coping ${ }^{(14)}$. In other words, to develop behavioral and cognitive skills that allow to control the demands of the internal and external environment, the management of the stressful event, the control, the reduction or even the elimination of emotional responses, since this process does not always happen harmoniously ${ }^{(17-18)}$.

Understanding this range of feelings and sensations, reflecting the dependence on a machine, requires nurses to have an attitude that arouses patients to look at themselves during the entire treatment, i.e., that in addition to giving time and a voice, instruct them to self-care. That is, to awaken self-perception, making them see themselves as the main protagonist of their health and treatment ${ }^{(18-19)}$.

Awakening self-perception requires nurses to dive into the most intimate of themselves, in order to know themselves and get to know the other, and also find ways to guarantee the recovery of autonomy ${ }^{(3)}$. Understanding care in these perspectives means associating it with a greater appreciation of life, extrapolating, through elements such as welcoming, attachment and accountability, the focus of attention to signs and symptoms, from the disease to the person, comprehensively ${ }^{(19)}$.

Comprehensive care is, therefore, aimed at the person, who needs multiple perspectives, multidisciplinarity, which is sometimes linked to a health system that is almost always transversal, in a network ${ }^{(20)}$. To perceive being intertwined in this process is a path towards the achievement of patients' autonomy and, also, making comprehensive care possible.

When considering these questions about comprehensive care, permanent health education, a set of actions that guarantee welcoming and guidance of patients and their families presents itself as an opportunity to improve treatment ${ }^{(21)}$. To make this therapeutic process, psychologists or even nurses must be present, directing their approach towards living with the process itself.

In the practice of nephrology service, thinking about comprehensive care is still a challenge, especially for nurses, considering the amount of 35 calls per work shift established by the Ministry of Health Ordinance 389 of 2014, not counting technical assistance, generating, in addition to gaps in the guarantee of welcoming and guidance, daily exhaustion on the health team ${ }^{(22)}$. Despite this limitation, on June 7, 2018, Ordinance 1,675 was instituted, which increases the number of nurses' attendance to 50 patients in each dialysis shift ${ }^{(23)}$.

It is up to these professionals, who work with patients with CKD, not only perform administrative and care functions, but also educational and research functions, mainly to try to make up for the shortcomings arising from primary care regarding early diagnosis and treatment ${ }^{(24)}$. Comprehensive care, therefore, must be preceded by the logic of intentionality, co-responsibility, collaboration and co-participation of those involved with assistance ${ }^{(20)}$.

\section{Study limitations}

The participation of nurses working in the studied practical field can be considered to be of little significance, seeing the process of effective changes in the professional approach to patients with CKD, in addition to the need to identify the intervening factors, the care demands and the elements of intersubjectivity that involves the perception of oneself and the other and interpersonal relationships. In this way, it is suggested its replication, with a wide range of participants, and in other realities, in order to verify the compatibility of the data with other services.

\section{Contributions to nursing}

The experience allowed nurses to reflect, in depth and content, on the care provided to patients with CKD, paying attention to psycho-affective aspects, reflected in the scenarios of tensions, anxieties, desires, needs and limitations common in the nephrology work environment. In some situations, these elements are present in the process of cognizable and cognizable communication that directly affects the interaction between nurse-patient-environment-treatment.

\section{FINAL CONSIDERATIONS}

The recommendations proposed by nurses focused on the exercise of empathy; monitoring patients' emotions from the implementation of the nursing consultation; continuous sharing of tensions, anxieties and desires; recognition of the emotion itself and the psycho-affective aspects of caring itself; increased availability to listen; the effectiveness of the team approach, as well as the creation of coexistence groups in the service. It is observed that such recommendations are powerful tools in the production of self-knowledge and self-perception by professionals, essential in learning and developing intellectual, psychological, affective, interactive and emotional skills for comprehensive health care.

The recognition and appreciation of the psycho-affective dimension by nurses reflects on the psychological and emotional context of patients in nephrology, requiring them to have greater scientific knowledge and technical skills to guarantee individual and group therapeutic support that encourages creativity, autonomy, solidarity and awareness. It also reinforces the importance of re-signifying spaces for coexistence in the service, favoring the process of welcoming patients' emotions and affections, whether through extended listening, dedication or even respect for the subjective experience with the disease. 


\section{FUNDING}

\section{Coordenação de Aperfeiçoamento de Pessoal de Nível Superior} (CAPES)

\section{ACKNOWLEDGMENT}

Escola de Enfermagem Anna Nery, Universidade Federal do Rio de Janeiro (EEAN/UFRJ).

\section{REFERENCES}

1. Vieira IFO, Santos FK, Silva FVC, Lins SMSB, Muniz NCC. Dialysis patient satisfaction with nursing care. Rev Enferm UERJ [Internet]. 2018 [cited 2019 Jan 20];26:26480. Available from: https://www.e-publicacoes.uerj.br/index.php/enfermagemuerj/article/view/26480/27039

2. Moreira AG, Azevedo AL, Figueiredo NM, Oliveira LP, Araújo ST. Proxemic behavior of nursing in the hemodialysis setting. Acta Paul Enferm [Internet]. 2017 [cited 2019 Jan 20];30(4):343-9. Available from: http://www.scielo.br/pdf/ape/v30n4/en_0103-2100-ape-30-04-0343.pdf

3. Azevedo AL, Araújo STC, Silva PS, Oliveira RMP, Dutra VFD. Nursing students' sense perception of communication in psychiatric hospital. Rev Bras Enferm [Internet]. 2018 [cited 2019 Jan 20];71(suppl 5):2280-6. Available from: http://www.scielo.br/pdf/reben/v71s5/0034-7167reben-71-s5-2280.pdf

4. Fernandes, LP, Marins KYM, Carmo HO, Silva SRS, Farias SMC, Silva CFG. Necessidades de ações educativas-terapêuticas em um serviço de diálise renal no Brasil. Enferm Nefrol [Internet]. 2018 [cited 2019 Jan 20]; 21(1): 53-62. Available from: http: http://scielo.isciii.es/pdf/enefro/ v21n1/2255-3517-enefro-21-01-53.pdf

5. Oliveira AM, Soares E. Uma Comunicação como Importante Ferramenta nas Orientações em uma Unidade de Hemodiálise: um estudo reflexivo. Saúde Soc Transform Saúde Mud Soc [Internet]. 2014 [cited 2019 Jan 20];5(3):118-23. Available from: https://www.redalyc.org/ pdf/2653/265335335017.pdf

6. Borges DCS, Furino FO, Barbieri MC, Souza ROD, Alvarenga WA, Dupas G. The social network and support of kidney transplantees. Rev Gaúcha Enferm [Internet]. 2016 [cited 2019 Jan 20];37(4):e59519. Available from: http://www.scielo.br/pdf/rgenf/v37n4/en_0102-6933rgenf-1983-144720160459519.pdf

7. Souza FTZ, Oliveira JHA. Sintomas depressivos e ansiosos no paciente renal crônico em tratamento conservador. Rev. Psicol. Saúde [Internet]. 2017[cited 2019 Jan 20];9(3):17-31. Available from: http://pepsic.bvsalud.org/pdf/rpsaude/v9n3/v9n3a02.pdf

8. Tong A, Sainsbury P, Critérios Craig J. Consolidated criteria for reporting qualitative research (COREQ): a 32-item checklist for interviews and focus groups. Int J Qual Health Care [Internet]. 2007 [cited 2019 Jan 20];19(6):349-57. Available from: http://intqhc.oxfordjournals.org/content/19/6/349.long

9. Bardin L. Análise de Conteúdo. São Paulo: Edições 70, 2011.

10. Terezam R, Reis-Queiroz J, Hoga LAK. The importance of empathy in health and nursing care. Rev Bras Enferm [Internet]. 2017[cited 2019 Jan 20];70(3):669-70. Available from: http://www.scielo.br/pdf/reben/v70n3/0034-7167-reben-70-03-0669.pdf

11. Ndemera $H$, Bhengu B. Perceptions of Healthcare Professionals regarding Self-management by kidney transplant transplant recipients in South Africa: a qualitative study. Int J Africa Nurs Sci [Internet] 2018 [cited 2019 Jan 20];9:120-8. Available from: https://www.sciencedirect. com/science/article/pii/S221413911830043X

12. Moreira JM, Matta SM, Kummer AM, Barbosa IG, Teixeira AL, Silva ACS. Neuropsychiatric disorders and renal diseases: an update. J Bras Nefrol [Internet]. 2014 [cited 2019 Jan 20];36(3):396-400. Available from: http://www.scielo.br/pdf/jbn/v36n3/en_0101-2800-jbn-36-03-0396.pdf

13. Maciel CG, Ferraz RN, França VV, Frazão IS, Borba, AKOT. Adesão ao tratamento hemodialítico: percepção dos pacientes renais crônicos. Cogitare Enferm [Internet]. 2015 [cited 2019 Jan 20];20(3):540-7. Available from: http://www.saude.ufpr.br/portal/revistacogitare/wpcontent/uploads/sites/28/2016/10/41112-163040-1-PB.pdf

14. Silva RAR, Souza VL, Oliveira GJN, Silva BCO, Rocha CCT, Holanda JRR. Coping strategies used by chronic renal failure patients on hemodialysis. Esc Anna Nery [Internet]. 2016 [cited 2019 Jan 20];20(1):147-54. Available from: http://www.scielo.br/pdf/ean/v20n1/ en_1414-8145-ean-20-01-0147.pdf

15. Savieto RM, Leão ER. Nursing assistance and Jean Watson: a reflection on empathy. Esc Anna Nery [Internet]. 2016[cited 2019 Jan 20];20(1):198-202. Available from: http://www.scielo.br/pdf/ean/v20n1/en_1414-8145-ean-20-01-0198.pdf

16. Pereira RTA, Ferreira V. A Consulta de enfermagem na Estratégia Saúde da Família. Rev Bras Multidiscip[Internet]. 2014 [cited 2019 Jan 20];17(1):99-111. Available from: http://www.revistarebram.com/index.php/revistauniara/article/viewFile/10/7

17. Kaiser DE, Dall'agnol CM. Teaching and learning nursing management in the hospital context: an approach in the light of Pichon-Rivière. Rev Esc Enferm USP [Internet]. 2017 [cited 2019 Jan 20];5(e3261). Available from: http://www.scielo.br/pdf/reeusp/v51/1980-220X-reeusp51-e03261.pdf

18. Xavier SSM, Germano RM, Silva IP, Lucena SKP, Martins JM, Costa IKF. Na correnteza da vida: a descoberta da doença renal crônica. Interface Comun Saúde Educ [Internet]. 2018 [cited 2019 Jan 20];22(66):841-51. Available from: http://www.scielo.br/pdf/icse/v22n66/1414-3283icse-1807-576220160834.pdf

19. Santos VFC, Borges ZN, Lima SO, Reis FP. Percepções, significados e adaptações à hemodiálise como um espaço liminar: a perspectiva do paciente. Interface Comun Saúde Educ [Internet]. 2018[cited 2019 Jan 20];22(66): 853-63. Available from: http://www.scielo.br/pdf/icse/ v22n66/1414-3283-icse-1807-576220170148.pdf 
20. Souza SM, Bernardino E, Crozeta K, Peres AM, Lacerda MR. Integrality of care: challenges for the nurse practice. Rev Bras Enferm [Internet]. 2017[cited 2019 Jan 20];70(3):504-10. Available from: http://www.scielo.br/pdf/reben/v70n3/0034-7167-reben-70-03-0504.pdf

21. Oliveira NB, Silva FVC, Assad LG. Competências do enfermeiro especialista em nefrologia. Rev Enferm UERJ [Internet]. 2015 [cited 2019 Jan 20];23(3):375-80. Available from: http://www.facenf.uerj.br/v23n3/v23n3a14.pdf

22. Ministério da Saúde (BR). Portaria № 389, de 13 de março de 2014. Define os critérios para a organização da linha de cuidado da Pessoa com Doença Renal Crônica (DRC) e institui incentivo financeiro de custeio destinado ao cuidado ambulatorial pré-dialítico. Brasília: Diário Oficial da União no 141 de 25 de julho de 2014.

23. Ministério da Saúde (BR). Portaria n 1.675, de 07 de junho de 2018. Altera a Portaria de Consolidação no 3/GM/MS, de 28 de setembro de 2017, e a Portaria de Consolidação n 6/GM/MS, de 28 de setembro de 2017, para dispor sobre os critérios para a organização, funcionamento e financiamento do cuidado da pessoa com Doença Renal Crônica - DRC no âmbito do Sistema Único de Saúde - SUS [Internet]. 2018[cited 2019 Jan 20]. Available from: http://bvsms.saude.gov.br/bvs/saudelegis/gm/2018/prt1675_08_06_2018.html

24. Vanderboom CE, Thackeray NL, Rhudy LM. Key factors in patient-centered care coordination in ambulatory care: nurse care coordinators' perspectives. Appl Nurs Res[Internet]. 2015 [cited 2019 Jan 20];28(1):18-24. Available from: https://www.ncbi.nlm.nih.gov/ pubmed/24746283 